\title{
A NOVEL 5 TITIK 1 KOMA BY MUHAMMAD KAMAL IHSAN ON PERSPECTIVE AL-GHAZALI'S SUFISM
}

\author{
Khairatun Nisa
}

\author{
Theology and Islamic Philosophy UIN Antasari \\ airaazura1@gmail.com
}

Diterima 29 Februari 2020 | Direview 13 Mei 2020 | Diterbitkan 30 Juni 2020

\begin{abstract}
This research was conducted the importance of Sufism as the spirit of Islam in the midst of modernity which erodes aspects of morality and buman spirituality. Now, the doctrine of Sufism is not only tanght in the formal as a recitation, but also conveyed through literature such as novel that attract the interest of society. A Novel 5 Titik. 1 Koma by Muhammad Kamal Ihsan is the one of a novel that contained the doctrine of Sufism and is applicable in life. Based on the description, the research is done by lifting the formulation of the problem which includes the contents of the novel 5 Titik 1 Koma by Muhammad Kamal Ihsan and see the novel by perspective of al-Ghazali's Sufism. The research is used the qualitative approach and the types is library research. The form of is document or text, that when examining a work of literature (fiction), in addition to interpret the contents of the document that separated from the author, it is also for digging someone's mind that contained in the literature. Technique of analysis that used in this research is content analysis, which analyze the dimensions of Sufism which is contained in the novel 5 Titik. 1 Koma. In this case, the author used explanative contents analysis, which is analyze the content of that in which there is testing certain bypotheses, also makes the relationship between the variables and other variables. The author reveals some variables such as aspects of Sufism which is contained in the novel 5 Titik 1 Koma works of Mubammad Kamal Ihsan, and see the relationship with Sufism on the al-Ghazali's perspective. The results of the research have include three things, there were: First, the contents of the novel is composed intrinsic and extrinsic element that has been in accordance with the rules of writing a literature form of the novel. Second, the Sufism aspect contained in this novel which is explained by al-Ghazali in the form of maqamat and abwal, include: repentance, patience and gratitude, zubud, tawakeal, mahabbah (love), sincerity, and honesty. Third, this novel also contains the formulation of happiness that will be achieved if humans have gratitude, patience, confidence, sincerity, honesty, and love.
\end{abstract}

Keywords: Novel, Sufism, al-Ghazali

\section{Background of Study}

In Islam, after the death of Prophet Muhammad there was born a new termed that was oriented toward morals and all charities which brought out a heart closer to Allah. This term is often known as Sufism and until now it has passed many phases and conditions ${ }^{1}$. Sufism will never subsided or lost the important role in modern era. Even it by increasingly human problems are complexity and crisis of mechanistic modernity, the Sufism has a role the spiritual mankind balance by materially is fulfilled. $^{2}$

Today, the Sufism is conveyed in a various termed of studies, lectures, formal and non-formal written, with hope of spreading a spirit of Islam rahmatan lil-'alamin

${ }^{1}$ Fadhlalla Haeri, The Element of Sufism, terj.Ibnu Burdah dan Shohifullah, vii.

${ }^{2}$ Muhammad Solikhin, Sufi Modern: Mewujudkan Kebahagiaan, Mengbilangkan Keterasingan (Jakarta: PT Gramedia, 2013), 15. 
that started in ourselves. There are many authors whose give a contribution by their written to convey the Islam esoteric and also literature aspects.

Bani Sudardi in Sastra Sufistik: Internalisasi Ajaran-Ajaran Sufi dalam Sastra Indonesia explained that there are many literatures which sufistic nuances that consisted explanation of ideas, doctrines, faiths, and the traits are taken from Sufism ${ }^{3}$. One of the Sufistic literary which is often found in the form of novel fiction. It is given that preaching can be done through various media and novels are a good choice to reach out to people who are less interested in reading religious books directly.

Novel 5 Titik 1 Koma which was launched on October 15, 2018 at UIN Antasari Banjarmasin, is a Sufism-based literary work. This novel was written by a student in the Hadith Study Program at al-Azhar Cairo, Egypt is named Muhammad Kamal Ihsan. He is an Indonesia student who born in Banjarmasin that introduced the beauty of Egypt and al-Azhar in a fictional story by including a background images of the story. By his story, he tried to make simpler of some aspects especially in teaching of al-Ghazali's Sufism and some aspects from Ibn-Athaillah specifically the aspects that can be practiced in a day of life then it can be understood and accepted by ordinary people easily. ${ }^{4}$

In his novel, he made formulates the aspects of life that must be passed to obtain peace of mind and true happiness. The aspects highlighted in the novel story are aspects of morals and charity of the main character, Zaritsa. Even though this woman named Zaritsa is a disabled (dumb) one, she can inspire others to find happiness by gratitude, patience, confidence, honesty, sincerity, and love.

It is a different fromthe other Sufic-fiction, this novel not only slipped the value of Sufism implicitly in the flow of the story, but also explained explicitly, clearly, and simply through reviews related to Sufism. This novel combines motivation and inspiration for readers to always live their lives to Allah's guidance.

Based on the description above, through by this study the writer want to conduct the novel 5 titik 1 Komawith analyze the content by Muhammad Kamal Ihsan on perspective of Al-Ghazali's Sufism. In addition, the author of this novel got many inspirations a concept of Al-Ghazali's Sufism, it is in accordance with AlGhazali's Sufism. It is contained a sunni Sufism based on a doctrine of Ablu as-Sunnah wa al-Jamálah, according to him the way of the Sufis is a blend of knowledge with charity, while the fruit is morality. ${ }^{5}$ For these reasons, this research is conducted.

Based on the background above, the main issues that raised are as follows:

1. How is the content of Novel 5 Titik 1 Koma by Muhammad Kamal Ihsan?

2. How is the content of Novel 5 Titik 1 Koma by Muhammad Kamal Ihsan according to perspective of Al-Ghazali's Sufism?

${ }^{3}$ Bani Sudardi, Sastra Sufistik: Internalisasi Ajaran-ajaran Sufi dalam Sastra Indonesia. Surakarta: Tiga Serangkai Pusataka Mandiri, 2003.

${ }^{4}$ Muhammad Kamal Ihsan, writer of 5 Titik 1 Koma, interview on Whatsapp, Egypt, 4 ${ }^{\text {th }}$ July 2018.

${ }^{5}$ Ahmad Zaini, "Pemikiran Tasawuf Imam Al-Ghazali", Esoterik: Jurnal Akblak dan Tasawuf, Vol. 2 No. 1, 2016, 146-157. 


\section{Research Method}

This research is used a qualitative research with type of library research. This study is analyzed the document or text a fiction, beside of do interpretation the document and it is also explored someone's opinion that consisted on the content. ${ }^{6}$

This research is used content analysis because analyzed the dimensions of Sufism that contained in the novel 5 Titik 1 Koma. In this case, the researcher used explanatory content analysis, it is contained analysis which testing of certain hypotheses, also trying to make a relationship between one variable to another variable. It was not only describe descriptively the contents of a message, but also tried to find the relationship between the contents of this message and other variables. ${ }^{7}$ The researcher will raise a several aspects that contained in a novel 5 Titik 1 Koma by Muhammad Kamal Ihsan, and find out the perspective on Al-Ghazali's Sufism.

\section{Types of Sufism}

The development of Sufism time to time has made a new term and types of Sufism. Asmaran As. Divided them to in three types, those are Moral Sufism, Amali Sufism, and Philosophical Sufism.

1. Moral Sufism

Sufism makes a systems that composed on the basic of education as an attempt to uncover the barrier, they are takhalli, taballi, dan tajalli. Takhalli means to clean a human self from despicable traits and inner also outer immorality which can pollute the human hearts. Tahall 1 is the stage of filling the soul that has been emptied before at the stage of takhalli, which is filling oneself with praiseworthy qualities with inner and outer obedience, familiarizing oneself with the nature and attitude and good deeds. Tajalli, which is the stage of the unfolding of the nurghaib for the heart. If the soul has been filled with noble qualities, then the members of the body will get used to doing good deeds, and good deeds so that further appreciation of God is needed so as not to diminish again. ${ }^{8}$

2. Amali Sufism

Amali Sufism is actually a continuation of moral Sufism, because before a person can be close to God with deeds, he must first cleanse his soul. This is because the cleansing of the soul is a condition for returning to God. If viewed from the aspect of practice and the type of knowledge learned, there are some terms that are typical in Sufism, especially Sufism Amali. Sufis divide religious teachings into zahir knowledge and inner knowledge which are then divided into four groups, namely Syar'ah, Thariqah, Haqîqah, and Ma'rifah. ${ }^{9}$

Syari'ah is rule or line that has been determined in Islam, including halal and haram laws, orders and prohibitions, things that are sunnah, change, and so on. Syarîa is the foundation for a Sufi or Sufi path to carry out worship especially those that are

${ }^{6}$ Eko Sugiarto, Menyusun Proposal Penelitian Kualitatif Skripsi dan Tesis (Yogyakarta: Suaka Media, 2013), 12

${ }^{7}$ Eriyanto, Analisis Isi: Pengantar Metodologi untuk Penelitian Ilmu Komunikasi dan Ilmu-Ilmu Sosial Lainnya(Jakarta: Prenadamedia Group, 2011), 49.

${ }^{8}$ Asmaran, Pengantar Studi Tasawuf, 65-93.

${ }^{9}$ Asmaran, Pengantar Studi Tasawuf, 93. 
zhabir such as prayer, fasting, almsgiving, pilgrimage, jihad, study, etc. in accordance with the main legal sources of the Koran and al-Hadith. Sufism can not be separated from the foundation of Islam, if there are those who claim to be folk but not in accordance with the teachings of Islam, it can be ascertained that the path it has taken has deviated. ${ }^{10}$

The implementation of syariah must be based on the procedures outlined in Islam and carried out solely as self-servitude to Allah, because of obedience to Allah and wanting to meet God. This journey to Allah is called thariqah tasawnf ${ }^{11}$. Tharígah in the view of the Sufis is a way or instruction in carrying out a worship in accordance with the teachings conveyed by the Prophet Muhammad ${ }^{12}$. This journey has begun to be of an inner nature, namely the practice of being born accompanied by inner practice. In thariqah stipulations that are of an inner nature so that the implementation of the zhâhir can lead one to the end of his journey, namely through stages and circumstances known as maqâmat and abwa . $^{13}$

Maqâmat is the stations that must be passed by the traveler of Sufism (sâlik), namely the spiritual level that has been reached by a Sufi. Maqâm (the singular form of maqâmatt) is the result of continuous sincerity and struggle. This means that a new person can rise from one maqâm to a higher maqâm after going through training and instilling better habits. Regarding the number and composition of the maqâmat, no similarities were found between the Sufis. ${ }^{14}$

Meanwhile abwal is a mental condition such as feeling happy, sad, afraid, and so on. Unlike the case with maqâm, things (the singular form of abwal) are not obtained through effort, but are obtained as gifts and blessings from Allah. Although this condition or mental attitude is a gift from God, those who want to improve the e intensity of his soul must try to make himself entitled to receive the gift, namely by increasing the quality and quantity of his deeds. It can be understood that the higher a person is, the higher the value is obtained. In other words, the mental condition obtained by a Sufi is a gift from the deeds he does. The number and composition of this article also has differences between Sufis as well as maqâm. ${ }^{15}$

Apart of syari'ab and thariqah, haqiqah is an inseparable aspect. Haqîqah is interpreted as another aspect of syari' ab which is inner. In other words as the deepest secret of all charity, the core of syariah, and the end of the journey taken by a traveler of Sufism. Haqiqah can also be called abwal because it is obtained as a favor and gift from God after going through spiritual practices. If thariqah has been taken seriously and holds faithful to the terms and pillars, then come to haqiqab ${ }^{16}$

In the other hand, ma'rifah means knowing Allah (ma'rifatullâh) with the truth which is the main goal in Sufism. According to Sufis, ma'rifah is the nature of people who know the names and attributes of God. The introduction and obedience to Allah is proven by practicing good deeds and leaving despicable deeds because they always remember Allah. That way, God will love him and give him gifts, taufik and

\footnotetext{
${ }^{10}$ Moh. Saifullah Al Aziz Senali, Risalah Memahami Ilmu Tasawuf, 69-70.

${ }^{11}$ Asmaran, Pengantar Studi Tasawnf, 96-97.

${ }^{12}$ Moh. Saifullah Al Aziz Senali, Risalah Memahami Imu Tasawuf, 77.

${ }^{13}$ Asmaran, Pengantar Studi Tasawuf, 96-97.

${ }^{14}$ Asmaran, Pengantar Studi Tasawuf, 104-106.

${ }^{15}$ Asmaran, Pengantar Studi Tasawuf, 137-138.

16Asmaran, Pengantar Studi Tasawuf, 98-101.
} 
hidayah so that he is always guarded so that he does not turn to anyone other than Allah.Therefore, ma'rifah can only be achieved through syari'ah, taking thariqab and obtaining haqîqah. If the syarìah and thariqab have been mastered, then haqiqah arises which is an improvement of the situation (ahwal), while the final goal is ma'rifah which is to know and love God truly. ${ }^{17}$

\section{Philosophical Sufism}

The philosophical Sufism is Sufism whose teachings combine mystic and rational. Unlike the case with moral Sufism and Amali Sufism which are still in Sunni Sufism such as Al-Ghazali's Sufism, philosophical Sufism uses philosophical terms in the expression of its teachings. These philosophical terms come from various philosophical teachings that influence the characters. These philosophical Sufism cannot be categorized into philosophy because the teachings and methods are based on taste (dzauq), nor can they be categorized as Sufism because many use philosophical terms and tend to pantheism. ${ }^{18}$

\section{Sufism in Al-Ghazali's view}

Abu Hamid Muhammad bin Muhammad al-Tusi al-Ghazali (450-505 H/105819 December $1111 \mathrm{M}$ ), is a moslem thinker, theologian, philosopher and a famous Sufis. ${ }^{19}$ Al-Ghazali was a multidimensional scholar who had encyclopedic knowledge and expertise. According to some scholars who studied Al-Ghazali, he has written at least as many as eighty papers covering various sects, namely Philosophy, Science of Kalam, Jurisprudence, Ushul Jurisprudence, Interpretations, Morals, Sufism, and so on. ${ }^{20}$

Sufism of Al-Ghazali has a sunnî pattern, namely tasawuf which is in accordance with the understanding of ablu as-sunnah wa al-jamá'ah. He taught Sufism and morality as a method for the Sufi paths to draw themselves closer to Allah. Although the background of his thoughts other than Sufism is philosophy, but he does not use philosophical terms in his Sufism, instead criticizing the philosophers and Sufi practices of his day. So that it can grow rapidly and be easily accepted by ordinary people. ${ }^{21}$

Al-Ghazali discussed the concepts of Sufism so comprehensively in the Book of Ihâ 'Ulum al-Din (reviving the religious sciences). Broadly speaking, the book Ibya Ulum al-Din consists of four volumes which are then divided into ten chapters in each volume. The division of the four volumes if observed contains different emphases in line with the stages of the journey and the struggle that must be taken by a sufi (sâlik) path. ${ }^{22}$

${ }^{17}$ Asmaran, Pengantar Studi Tasawuf, 103-104.

${ }^{18}$ Asmaran, Pengantar Studi Tasawnf, 149-150.

${ }^{19}$ Dewan Redaksi Ensiklopedi Islam, Ensiklopedi Islam. Vol. 2 (Jakarta: PT Ikhtiar Baru van Hoeve, 2001), 25.

${ }^{20}$ There are many differences in terms of $\mathrm{Al}$-Ghazaly literary as a references, e.g in Ensiklopedi Islam is mentioned about 100 copies. Meanwhile, in Ensiklopedi Tasawnf is mentioned that the written by him almost 400, and also there are 50 books and flier is written by Al-Ghazali. As an explanation by Al-Qardawi, it is hard to do an accuracy is because there was a lost and tried to be duplicate and gave name since Al-Ghazaly born.

${ }^{21}$ Al-Ghazali, Arbain Al Ghazali, trans. M. Said Su'di (Yogyakarta: Pustaka Sufi, 2003), xii.

22Zaprulkhan, Ilmu Tasawuf: Sebuah Kajian Tematik, 134-135. 
In the fourth volume of Ibya 'Ulum al-Din in the munjizat section, we can see a Sufism Al-Ghazali's thinking especially about maqâmât and abwâl, including repentance, patience and gratitude, hope and fear, devotee and zubûd, taubid and tawakkal, love, longing, pleasure, and sincere and honest. ${ }^{23}$

\section{Sufism as a Way to Reach Happiness}

Happiness is a term commonly used, both by philosophers and Sufism experts, to explain a condition that has always been the goal of every human being, as a creature who wants to achieve its perfect existence. ${ }^{24}$ Everyone craves happiness, even though different views concern what gives happiness. Happiness is good and pleasant according to each person. ${ }^{25}$

Although happiness tends to be relative, many experts try to express happiness scientifically. Even Denny $\mathrm{JA}^{26}$ summarizes the results of research on happiness for around decades from various scientific disciplines, from psychology, sociology, economics, politics, to neuroscience. He formulated it into five mindsets and habits to live happily, namely personal relationships, positivity, passion, small winning, and spiritual life. ${ }^{27}$ Denny JA said that spiritual life regarding the relationship between religion and happiness is one of the most popular topics in happiness studies involving many researchers. ${ }^{28}$

In Islam itself, Sufism is the biggest way to achieve happiness. As a Muslim who practices Islamic teachings in every line of life, the true teachings of Sufism can lead to ultimate happiness. Not just happiness which is relative or physical happiness, but the happiness of the soul as mentioned by Ibn Miskawaih. Happiness of the soul is the highest happiness, the soul that is one with the body is a soul that is still dirty because it still has desires. If there is still desire in the soul, then it will not arrive at the highest happiness. Both Ibn Miskawaih and Al-Ghazali stated that happiness can only be obtained in the afterlife or after death. ${ }^{29}$ In Kimyâ As-Sa'adab (The Alchemy of Happiness) Al-Ghazali mentions that there are four elements that must exist to obtain spiritual happiness, namely knowledge about self, knowledge of God, knowledge of the world, and knowledge of the hereafter. ${ }^{30}$

\section{A Novel 5 Titik 1 Koma by Muhammad Kamal Ihsan}

Literary works are composed by two elements that compose them, namely extrinsic elements and intrinsic elements. Extrinsic elements are elements that compose a literary work from the outside. While the intrinsic element is the element that composes a literary work from within which embodies the structure of a literary work $^{31}$. The extrinsic and intrinsic elements of the novel 5 titik 1 koma are as follows:

${ }^{23} \mathrm{Abu}$ Hamid Al-Ghazali, Ibya 'Ulum Al-Din, Vol. 4 (Beirut: Dar al-Kutub al-Ilmiyah, 2015).

${ }^{24}$ Imam Sukardi, Puncak Kebahagiaan Al-Farabi: Etape-etape Sufistik-Filosofis Meniti Revolusi Hidup (Yogyakarta: Pustaka Pelajar, 2005), 83.

${ }^{25}$ M. Quraish Shihab, Yang Hilang dari Kita: Akblak (Tangerang: PT. Lentera Hati, 2016), 47.

${ }^{26}$ Denny JA, as a intellectual entrepreneurwho made an innovation in academic, politic, social media, literature and culture in Indonesia. Since 2000, he is deepen of many research in sect of psychology, neuroscience, and humanity study that related a joyful concept.

${ }^{27}$ Denny JA, Bahagia itu Mudah dan Imiah (Depok: Kata Depan, 2017), xiii-xiv.

${ }^{28}$ Denny JA, Bahagia itu Mudah dan Ilmiah, 301.

${ }^{29}$ Imam Sukardi, Puncak Kebahagiaan Al-Farabi, 92-93.

${ }^{30}$ Al-Ghazali, Kimiya Al-Sa'adab: Kimia Rubani untuk Kebahagiaan Abadi, terj. Dedi Slamet Riyadi dan Fauzi Bahreisy (Jakarta: Zaman, t. th), 5-6.

${ }^{31}$ Redaksi PM, Sastra Indonesia, 4. 
1. Extrinsic Elements

a. Writer biography

Muhammad Kamal Ihsan was born in Banjarmasin on August 12, 1994. He was the last of three children from the couple Muhammad Haderan (Alm.) And Dra. Dahliani. His mother educated him alone and always instilled the belief that against anything, if there was a will, he certainly could. Now he is studying at Al-Azhar University, Cairo, Faculty of Hadith Science, Faculty of Ushuluddin. Previously he was educated at MTsN Mulawarman Banjarmasin, Darussalam Gontor Modern Cottage and memorized the Qur'an at Pondok As-Syadzily li Tahfidzil Qur'an. Muhammad Kamal Ihsan is known to be critical and active in reviving student organizations, besides that he is also active in writing especially in the field of literature, and even won several writing competitions. ${ }^{32}$

b. Background of the Author's Thought

Novel 5 titik 1 Koma was written by Muhammad Kamal Ihsan with the intention of preaching to convey things that have been close to humans, even always mentioned. However, this novel is rarely understood in depth and is defined as its essence. This novel is an author's effort to simplify the delivery of Sufism which is considered complicated to be accepted by ordinary people. In addition, the author also wants to introduce Egypt and Al-Azhar as places to study in the wider community. ${ }^{33}$

Muhammad Kamal Ihsan tried to convey Sufism through his novel because according to him Sufism is one of the buffer of Islam and is very important to balance life. At Al-Azhar where he studied was taught about Sufism in depth. This novel is tinged with Sufism Al-Ghazali, especially Ihâ 'Ulûm ad-Dîn because it is considered a phenomenal work that collects all religious guidance, not only Sufism but also jurisprudence and faith. This is because Al-Ghazali is a Sufi figure whose knowledge is evenly distributed in all fields. The Book of Ihâ 'Ulûm ad-Dîn is considered to be so close to society and widely known even to ordinary people. ${ }^{34}$

1. Intrinsic Elements

a. Theme

Themes are issues that could be the main topics in literary works. A very prominent theme is called a major theme, and a non-prominent theme is called a minor theme. ${ }^{35}$ The major theme in the novel 5 Titik. 1 Koma by Muhammad Kamal Ihsan is the struggle of an Indonesian woman named Zaritsa with her mute limitations, in the land of Egypt. The minor theme in this novel is Egypt as the oldest historic city in the world, a place that is much aimed at exploring Islam and rich in its abundant knowledge, with Al-Azhar as the center of Islamic science.

b. Actors and Characteristics

People are actors in literary works. Usually in literary works there are several figures with one main character. The main actor is a figure who plays an important

${ }^{32}$ Muhammad Kamal Ihsan, 5 Titik 1 Koma (Bandung: CV. Rasi Terbit, 2018), 276-278.

${ }^{33}$ Muhammad Kamal Ihsan, writer of noel 5 Titik 1 Koma, interview on Whatsapp, Mesir, 4 th July 2018.

${ }^{34}$ Muhammad Kamal Ihsan, writer of novel 5 Titik 1 Koma, interview on Whatsapp, Mesir, $4^{\text {th }}$ July 2018.

${ }^{35}$ Redaksi PM, Sastra Indonesia,5. 
role in the literary work. ${ }^{36}$ While characteristic or characterization is a technique of displaying characters. ${ }^{37}$

1) Zaritsa

Zaritsa is the main character in this novel. Her full name is Zaritsa Putri Cahaya, a girl from South Kalimantan who is studying at Al-Azhar Cairo. She is poor and has physical limitations (dumb). She is a woman who always passionate, obedient to her teacher, and inspiring. The characterization of Zaritsa is known through stories of people who have known her also known through her notebook found by Ihsan.

2) Ihsan

His full name is Muhammad Ihsan Kamal, a senior student at Al-Azhar. He is care and helpful. He traveled to return the book of a dumb woman named Zaritsa who had missed the bus.

3) Hisyam

Hisyam is an 8 years old with curly hair who works everyday as an isy seller after stopping being a pickpocket to save his father. He is a child who is responsible and willing to sacrifice.

4) Zakiah

An Indonesian student who became Zaritsa's friend, she could understand sign language. She is kind, caring, sympathetic, wise and helpful. 5) Mala

A little Egyptian native girl met by Ihsan. Even though she was still small, she was very religious.

6) Malik

Malik is a younger brother of Zakiah who only studied at Al-Azhar for 2 years. He was sent by Zakiah to go along with Ihsan to Sinai to find the address of the person close to Zaritsa. He also knew Zaritsa well.

7) Zaid

Zaid is also a student of Al-Azhar, a friend of Malik. He is a handsome, calm, eye-glasses. He had considered Zaritsa like his own brother. He had wanted to surrender in memorizing the Qur'an, but Zaritsa continued to encourage him to continue fighting and not giving up.

8) Ghazali

Ghazali is often called Zali, also a friend of Malik. Initially he was so stubborn that he was almost expelled from the dormitory, he finally turned out to be good thanks to Zaritsa.

9) Hisyam's father

Hisyam's father was angry and cruel. His condition is poor and debtridden. He works everyday with the help of machines, to be sold by Hisyam.

10) Raka

His full name is Raka Perdana Putra. It is about 2 or 3 years older than Ihsan. He lives in Aswan, being an Imam Mosque, his voice is sweet.

11) Zaritsa's father

\footnotetext{
${ }^{36}$ Redaksi PM, Sastra Indonesia,5.

${ }^{37}$ Redaksi PM, Sastra Indonesia,6.
} 
Often called Abah, he was a patient person, never giving up despite his limitations. Simple men who are also dumb since birth as Zaritsa.

12) Mahmud Abdullah

Black man who brought Raka with Zaritsa. He is a teacher of Zaritsa who he has considered like his own father. One of the best graduates at AlAzhar, alim, shalih, and tawadhu.

13) Sheikh Ahmad Tanthawi

He is a teacher from Mahmud Abdullah who has completed studies at Al-Azhar to the doctoral level and respected hadith experts. He cannot see since childhood, but has memorized the Qur'an since he was 7 years old.

Besides the figures above, there are other figures present in this novel but only as a complement, so it is not mentioned.

c. Plot

The path in a story is also called a plot, which is a series of events that have a causal relationship, to become a unified whole. The flow of the novel consists of several stages or sections. ${ }^{38}$

1) Begin

The first part is the author begins to introduce the actors ${ }^{39}$. The initial stage of the novel is the incident when Ihsan found a notebook left on the bus in Cairo belonging to a mute woman named Zaritsa. His admiration for the owner of a book he had never known and his desire to return it brought Ihsan to his long journey.

The introduction of other figures starting in chapters 1-4 which shows Ehsan to the next clue to get to know Zaritsa better. Ihsan's journey began from Cairo to Alexandria, then proceeded to Sinai. Here he re-learned the feeling of "gratitude" which was also explained by the author clearly and simply.

Then he came to know the little son of the isy named Hisyam and Zakiah who was also willing to help Hisyam sell his issh. Then Zakiah introduced Zaritsa further to Ihsan through the story of her first meeting. Zakiah also gave the address of someone who was very familiar with Zaritsa to Ihsan. The author again explains clearly and simply about "Patience".

2) Conflict

Twists are conflicts that occur between figures ${ }^{40}$. The first conflict that occurred when Ihsan together with Malik, Zaid, and Zali climbed Mount Sinai. At the end of this section Malik, Zaid, and Zali also briefly told about the figure of Zaritsa. At the end of this section the author again explains about "Sure".

Then the story moves to Hisyam after he is delivered home by Ihsan. Hisyam recalled the incident when there was a dumb woman who also helped her from the tantrums of people who wanted to burn her body. At that time he was caught pickpocketing, and before the mute woman had also acted pickpocketed and told him to be honest by returning the money he had taken. This mute woman is none other than Zaritsa.

\section{3) Rumination}

${ }^{38}$ Redaksi PM, Sastra Indonesia, 6.

${ }^{39}$ Redaksi PM, Sastra Indonesia, 7.

${ }^{40}$ Redaksi PM, Sastra Indonesia, 7. 
The rumors of conflict are increasingly exciting figures. ${ }^{41}$ Ihsan who initially thought the address addressed by Zakiah was located in the Sinai area turned out to be wrong. The area in question is Aswan. Ihsan finally continued his journey alone without Malik, Zaid, and Zali. Hinga finally found the address, Ihsan, an old flat in Aswan. The owner of the house was named Raka and told Ehsan to rest at his house. At the end of this section until the beginning of the next section the author explains "Honest".

Then Zaritsa tells about her and her father whom she loves the most. At that time he read his father's letter which indicated that he had died. While Raka told Ihsan the beginning of the incident which later brought him to Zaritsa. In this section, Raka tells how he used to hate Egypt until his meeting with the Kernet bus named Mahmud which had changed the course of his life. Mahmud told him to meet someone at the Al-Azhar Mosque. At the end of the story he said to Ihsan that he loved Zaritsa very much. Suddenly Ihsan was so jealous to hear Raka's words. The author then explains about "Sincerity".

Raka recounts his first meeting with Zaritsa. At first he felt Zaritsa was underestimating him for refusing to shake hands with him, even having time to say rude to Zaritsa. He was so shocked to learn that Zaritsa had been dumb from birth. Then through Mahmud Zaritsa asked Raka to go along with them to Luxor. Zaritsa was very enthusiastic and really wanted to change and awaken Raka's thoughts about Egypt.

Raka who initially did not want to go finally made his best decision. He left, his heart began to melt and began to admire Zaritsa. In Luxor, Raka's admiration for Zaritsa began to increase. Mahmud then invited both of them to meet with his teacher named Sheikh Ahmad Tanthawi who was blind from childhood. Teacher Tanthawi also admired Zaritsa through Mahmud's stories about him. Raka was even more moved when she saw how difficult the blind Teacher Tanthawi wanted to communicate with the silent Zaritsa, but they remained grateful and did not condemn the situation, even Teacher Tanthawi gave lessons that opened Raka's mind. That perfect meeting changed his life.

Raka then said to Ehsan that he loved Zaritsa very much, although all he could do was pray for his love, and greet Zaritsa through his prayer. Ihsan at that time really felt jealous. But then Raka told Ehsan to meet Zaritsa at the place of Mahmud's teacher. Ihsan's jealousy turned happy and hopeful, to a woman he had never even met. The author then explains about "Love".

4) Climax

The climax is when the last of conflict between the actors. ${ }^{42}$ Ihsan returned to Cairo and returned to reading Zaritsa's notebook while on the way. At the end of his writing, Ihsan read a statement about Zaritha's love that would never be revealed to someone he didn't know. Ihsan then felt jealous again. The next section tells of the incident at night when Zaritsa was intercepted by an Egyptian man and tried to injure him when he wanted to head to the house of his teacher, Mahmud.

Amid Zaritsa's fear, Hisyam suddenly rescued with an Indonesian man, Ihsan. People came to hear Hisham's shout which had shocked the Egyptian man. Ehsan

${ }^{41}$ Redaksi PM, Sastra Indonesia, 7.

${ }^{42}$ Redaksi PM, Sastra Indonesia, 7. 
fought with the Egyptian man and he was injured. Ehsan recognized Zaritsa, but Zaritsa did not recognize who he was. Zaritsa then took them to Mahmud's house. Ihsan was finally able to return the book directly and thank you. Ihsan also conveyed Raka's message, about his marriage. The news that rocked Zaritsa's soul.

5) Breakdown

Dispersion that is when the conflict event subsides and the development of the plot begins to unfold. ${ }^{43}$ This section is titled "Confession" which begins with a letter from Zaritsa to Zakiah about her marriage, in her writing, Zaritsa expresses her happiness how lucky Zakiah is to have a husband whom she knows his kindness. On the day of his marriage to Raka, Zakiah was so looking forward to Zaritsa's arrival but that did not happen. Even though it was a happy day for Zakiah and Raka, it was not for Zaritsa.

Moving on to the story of Ihsan who followed Mahmud's words to visit his little surau, he saw Zaritsa teaching people who were also mute like sign language. Suddenly Mahmud came and asked without further ado, whether Ihsan loved Zaritsa. Mahmud says that Zaritsa is looking for a replacement for her father's love. After some time thinking, finally Ihsan agreed.

6) A Happy Ending

The end is that all events or conflicts have been resolved. ${ }^{44}$ The final part of the story is titled "Pyramid and the Last Twilight", which contains the marriage of Ihsan and Zaritsa. Almost all figures gather here. At the end, Ihsan and Zaritsa share happiness in front of Pyramid.

This part is the culmination of happiness in the novel, which is the part where everyone is happy together for the happiness of the people they care about. However, the novel's author states that happiness is only false happiness, because it is still worldly. True happiness is akhawi happiness obtained through obedience and full servitude to God.

Muhammad Kamal Ihsan formulates that there are six aspects that must be possessed to achieve true happiness. These six aspects are gratitude, patience, confidence, honesty, sincerity, and love which are described through each part of the story.

While channeling is a technique for displaying grooves. Based on the quality, the distribution is divided into tight grooves and loose grooves. Close grooves are grooves without branching stories, while loose grooves are grooves that allow story splitting. According to the quantity, the distribution is divided into single grooves and double grooves. Single groove is only one groove, while double grooves are more than one groove. Based on the time sequence, the distribution is divided into straight and not straight grooves. Straight flow is a plot that describes events in sequence from the beginning to the end of the story. Conversely, a non-straight groove is a plot that describes the events in the story in an irregular manner. A nonstraight line can use backtracking, flashback, or a mixture. ${ }^{45}$

Based on its quality, the distribution of this novel uses loose grooves because it contains story splits. According to the quantity, the channel uses multiple grooves. Whereas in the order of time, the distribution of stories in this novel is a mixed flow.

${ }^{43}$ Redaksi PM, Sastra Indonesia, 7.

${ }^{44}$ Redaksi PM, Sastra Indonesia, 7.

${ }^{45}$ Redaksi PM, Sastra Indonesia, 7. 
That is, when the story goes forward, several times a number of flashback pieces are displayed that explain the background of the story.

d. Setting

The place of story is also called a setting, namely the place or time of the occurrence of events that occur in a literary work. The background itself is divided into material background and social background. Material setting is a painting of the natural background or environment in which the character is located. Social settings are paintings of behavior, customs, and life views. While the courtyard is a technique of displaying setting. ${ }^{46}$

The material background of this story is generally in Egypt, namely the Cairo area, Alexandria, Sinai, Aswan, Luxor, and Siwa with several different points. Background is described by the author through story text and several images. The material background of this story includes:

1) Inside the bus

2) Beaches and the Alexandria Street

3) Bukit Sinai

4) Old market

5) Old Flats

6) Small Surau

7) Luxor

8) Dark Road Near Mahmud's House

9) Al-Azhar Mosque

10) Pyramid

Whereas the social setting in the novel is described by the author through a monologue and dialogue between characters who describe the strengths possessed by Cairo, without describing the role of the antagonists in Cairo. In this section the author describes Alexandria's social conditions, he compares the differences between the two. In other parts, the author describes the habits of the Egyptian people who used more buses as a means of transportation, especially the students of Al-Azhar.

e. The Point of View

The point of view is where the story is told by the storyteller. There are two kinds of perspectives: the narrator as the first person and the narrator as the third person. ${ }^{47}$ The perspective used in this novel is a mixed viewpoint. This viewpoint uses the first person more as a storyteller, but there are some parts that use a third person's perspective.

f. Meaning

The meaning is the solution that given by the author to the problem in literature. The meaning is divided into the meaning and meaning of the charge. The intention is the meaning intended by the author for his literary works, while the meaning of the charge is the meaning contained in the literary work. ${ }^{48}$

The meaning of the intention contained in this novel is to obtain true happiness, need to have gratitude, patience, confidence, honesty, sincerity, and love with the truth to God. The meaning of the content contained in the novel is that the

\footnotetext{
${ }^{46}$ Redaksi PM, Sastra Indonesia, 7-8.

${ }^{47}$ Redaksi PM, Sastra Indonesia, 8.

${ }^{48}$ Redaksi PM, Sastra Indonesia, 5.
} 
limitations of both property and physical conditions do not prevent anyone from continuing to study and benefit others.

\section{A Novel 5 Titik 1 Koma by Muhammad Kamal Ihsan According to Al- Ghazali's Sufism}

Sufism Al-Ghazali is a Sunniof Sufism patterned, which is Sufism in accordance with Ablû as-sunnah wa al-jamâ'ah. It taught Sufism and morality as a method for the Sufi paths to bring themselves closer to Allah ${ }^{49}$. As revealed by Ahmad Zaini among Sufism Al-Ghazali's are: First, about maqâmât, according to Al-Ghazali there are several levels that must be passed by a Sufi it repentance, patience, fidelity, zuhud, tawakal, and ma'rifah. This ma'rifah then raises mababbah (loving Allah). ${ }^{50}$

Novel 5 Titik 1 Koma by Muhammad Kamal Ihsan is a novel fictional literary has been containing Sufism values. This novel tells the story of the main character of a mute woman named Zaritsa who through the beauty of her morals, she can change the lives of those who know her. Through the storyline, a glimpse of Sufism can be said that this novel tends to lead towards morality. This is evident from the influence of Zaritsa who became God's guidance to change the people who knew him to be a person with morals better than before. Many were aware of his negligence after getting to know the figure of Zaritsa who had never complained about all her shortcomings. Many who improve themselves, cleanse their souls filled with various bad temperament such as endless complaints, anger, and ambition towards a temporary world.

In addition to telling the story of a girl who has limitations in her physical abilities, this novel is also accompanied by reviews related to Sufism. Among them were an explanation of the five "titik" that must be passed and one "koma" that must always be there without ever ending. These five 'points' are patience, gratitude, confidence, honesty, and sincerity, while one 'koma' which must always be there is love or mahabbah.

The five 'titik' and one 'koma' that described in the novel's comments in Sufism teachings are included in Amali Sufism, namely Sufism which is more oriented to inner deeds. Patience, gratitude, confidence, honesty, sincerity, and mahabbah are included in the discussion of maqâmât and abwâl, namely the levels and spiritual conditions of those who travel to God. In addition to the six levels and spiritual conditions described in the novel 5 Titik 1 Koma, there are other maqâm and hâl which are also found in this novel.

As with Sufism Al-Ghazali, the novel 5 Point 1 Koma by Muhammad Kamal Ihsan has the akblaki Sufism and even amali sufism without any philosophical sufism elements. This is because most of the reviews contained in this novel are quoted from the literature of al-Ghazali who indeed has a sunnî pattern. Although some of the reviews are quoted from the literature of Ibn Atha'illah which some consider to be philosophical sufism because it emphasizes theology, according to the author, it still has a sunnî pattern. Among the aspects of Sufism contained in the novel 5 Titik 1 Koma according to al-Ghazali's perspective, namely:

1. Repentance

${ }^{49}$ Al-Ghazali, Arbain Al Ghazali, terj. M. Said Su'di, xii.

${ }^{50}$ Ahmad Zaini, "Pemikiran Tasawuf Al-Ghazali", Esoterik: Jurnal Akhlak dan Tasawuf Vol. 2 No. 1, 2016, 158. 
Although it is implied and is not explained clearly, the novel 5 Titik 1 Komaby Muhammad Kamal Ihsan contained aspects of repentance. This departs from the story of Hisyam who regrets his actions which have taken a lot of money from the wallet of many people who were picked up. He promised sincerely in his heart and told Zaritsa that he would not repeat the act even if he was forced. In addition, he also apologized to the people in the market for their actions that harmed them ${ }^{51}$. His remorse is evidenced by his hard efforts to spend his Islamic sales without ever thinking of returning to his bad work, even though he must starve.$^{52}$ Repentance will not stop only in remorse, but it must also be proven that bad and wrong actions will not happen again. The story of Hisyam illustrates a person's attempt to repent of the mistakes he had made. Proof is done by Hisyam which is called Al-Ghazali as an act or fruit that follows regret. ${ }^{53}$ Hisyam's apology to the people he had hurt was also a condition of repentance if the mistake he made was related to someone else. ${ }^{54}$

2. Patience and Gratitude

Patience and gratitude in this novel are reviewed separately to become 'two points' that must be passed and owned by someone to achieve happiness in his life. These two aspects seem to be the main themes in this novel. Because in life patience and gratitude must be owned in a balanced manner. As mentioned by Al-Ghazali that in fact the faith is divided into two parts. Half lies in patience and half lies in gratitude. ${ }^{55}$ This is described by Zaritsa as the main character in the novel as a woman who has fused a sense of patience and gratitude in her, through the state of her heart that is always happy even though she can see so many tests. In fact, it is no longer the patience that he feels for the limitations in his life as if all lacks, but precisely the gratitude for every situation that God has bestowed on him, even though for some people it is considered a disaster.

This is what Al-Ghazali called that patience and gratitude can complement each other, and both are related to one another. He mentions that disasters exist as well as they are and both are the opposite. Then the loss of disaster is a pleasure and the loss of pleasure is a disaster. But keep in mind that pleasure itself is divided into absolute blessings from all sides, and delights that are bound to only one side but not to the other. Absolute pleasure from all sides itself is divided into two, namely: the pleasure in the hereafter, such as the happiness of a servant who is located beside Allah SWT; and favors in the world such as faith, good morals and which deliver to both. Favors that are bound to only one side such as assets that can bring good to the religion on the one hand, and can damage religion on the other. ${ }^{56}$

Likewise with disasters, there are absolute and some are bound. So patience in the world returns to a disaster that is not absolute, but it can be a pleasure on the one hand. Therefore the task of patience and gratitude can be collected. For example health benefits, many servants who have more goodness when in poverty and at the

\footnotetext{
${ }^{51}$ Muhammad Kamal Ihsan, 5 Titik 1 Koma, 128-133.

${ }^{52}$ Muhammad Kamal Ihsan, 5 Titik 1 Koma, 38.

${ }^{53}$ Abû Hâmid al-Ghazali, Ibya 'Ulum Ad-Din, Vol. 4, 5.

${ }^{54}$ Abû Hâmid al-Ghazali, Ihya 'Ulum Ad-Din, Vol. 4, 22.

${ }^{55}$ Abû Hâmid al-Ghazali, Ibya 'Ulum Ad-Din, Vol. 4, 80.

${ }^{56}$ Abû Hâmid al-Ghazali, Ibya 'Ulum Ad-Din, Vol. 4, 169.
} 
time of illness. Whereas if he is healthy and has many possessions, he is arrogant and transgresses. ${ }^{57}$

Raka is also one of the characters in the novel who is described as having a problem regarding this thanksgiving. At first, he refused his destiny in Egypt which he considered to have taken his dream of becoming a doctor, before he was later met with Zaritsa. At Raka's first meeting with Zaritsa, Raka, who was initially stern and harshly angry with Zaritsa, became aware of Zaritsa's positive response.

Al-Ghazali mentions this kind of situation that Allah does not create anything, except for the creation of wisdom, and pleasure. Which is delicious sometimes for all of His servants or for some of them. Even God created disasters as well, both for those affected by the disaster or other people who were not affected by the disaster. So, every situation cannot be characterized as absolute that it is a favor or a disaster. So for a servant to gather patience and gratitude together. ${ }^{58}$

In this novel, Muhammad Kamal Ihsan as the author emphasizes the importance of gratitude. The only place to give thanks is only to Allah Almighty, both with heart, oral, and all parts of the body. ${ }^{59} \mathrm{Al}$-Ghazali mentions the application of gratitude with the heart which is intended to be kind to all beings, always presenting Allah in his dzikir and never forgetting Him. Gratitude orally through praise and gratitude that shows that he thanked God. While gratitude with members of the body that is using the blessings of Allah to obey Him and stay away from the use of His favors to disobey Him. ${ }^{60}$

In addition to gratitude, in this novel patience is also described as taking on a very important role in life. Not only from Zaritsa with the exams she had gotten from birth, patience was taught, but also from a little boy, an isy seller named Hisyam who was threatened by his father, he could not go home if he failed to sell all of these issues. Ihsan and Zakiah discovered the meaning of patience after successfully helping Hisyam to sell isy. The patience they feel is referred to by Al-Ghazali as a patient body, which is patient in enduring hardship with the body and remaining steadfast in all difficulties. ${ }^{61}$

After learning about the gratitude of Zaritsa through her writing, Ihsan learned it again through the story told by Zakiah about Zaritsa. Especially when Ehsan found that his cellphone had been stolen. This is what Al-Ghazali referred to as being patient in the face of disaster, because Ehsan felt the loss of his cellphone was a disaster for him. And the opposite of it is a condition called complaining or restlessness, which is a condition that drives absolute lust such as hardening sounds because of anger, hitting cheeks, damaging clothes, and actions caused by other anger. ${ }^{62}$

It was different from what Zaritsa felt if she had a small disaster like this, because she always felt that everything she had in the world was just a fake deposit and not too valuable compared to what God had promised in the hereafter. So he prefers to be patient and grateful for everything that happens in his life.

\footnotetext{
${ }^{57}$ Abû Hâmid al-Ghazali, Ihya 'Ulum Ad-Din, Vol. 4, 169-170

${ }^{58}$ Abû Hâmid al-Ghazali, Ibya 'Ulum Ad-Din, Vol. 4, 170-171.

${ }^{59}$ Muhammad Kamal Ihsan, 5 Titik 1 Koma, 17-21.

${ }^{60}$ Abû Hâmid al-Ghazali, Ibya 'Ulum Ad-Din, Vol. 4, 112.

${ }^{61}$ Abû Hâmid al-Ghazali, Ibya 'Ulum Ad-Din, Vol. 4, 88.

${ }^{62} \mathrm{Abû}$ Hâmid al-Ghazali, Ihya 'Ulum Ad-Din, Vol. 4, 88.
} 
Regarding this, Al-Ghazali quoted the words of Prophet Dawood as. to Prophet Sulayman as. "It can be used as a proposition on the piety of a Mu'min with three cases, which is good, presumably on what he cannot achieve, good pleasure on what he can achieve, and good patience for what has been lost." Then Al-Ghazali also mention a history of some pious people, that one day he came out and in his sleeve there was a bag of money, then the person lost his bag of money. It turned out that the bag of money had been taken by someone from his sleeve, then he said, "may Allah bless him in the pocket of money, maybe he needs it more than me". ${ }^{63}$

3. Zuhud

Zuhud is also one of the values that must be present in Sufism and also contained in this novel, although it is not explicitly stated by Muhammad Kamal Ihsan as the author. One of them was when he described the condition of some Cairo people who were so concerned about the claimants of knowledge around them. Even more prioritizing students who study religion and come from various countries, rather than themselves by giving their assets.

Egyptian society is described as more concerned with the needs of migrants who are currently studying science, especially religion in their country. Even if they don't care about the property only for themselves. This can be referred to as zuhud, as mentioned by Al-Ghazali that one degree of the person who commits zuhud is that if a person commits adultery against the world voluntarily on his own accord because he views the world as inferior to what he wants. Just like leaving one dirham after two dirhams, and he had no difficulty in adultery, but still heeded his condition. Even if they don't feel that they are adultery, this can reach the highest degree of zuhud, because they think they are not leaving anything. ${ }^{64}$

Zuhud is also portrayed through the figure of Mahmud who already has a position in the world, the best graduates of al-Azhar, respected people, scholarship and skills are undoubted, but prefer to become a bus train in the afternoon, because he feels that he can study from the various characters of the people he met on the bus. Mahmud never felt that he was a tall, great, and domiciled person, he kept doing what he wanted to do as long as it did not neglect him from God.

Al-Ghazali called this situation zuhud to the world, namely people who leave worldly advantages and do not like them, then he likes what is in the hereafter. Because Al-Ghazali mentions that zuhud must be accompanied by knowledge (knowledge) that the Hereafter is better than the world, also practice that proves his love for the Hereafter. ${ }^{65}$

\section{Tawakkal}

Tawakkal is described once in this novel, which is when Zaritsa is confronted by an Egyptian man who has evil intentions on him. After trying his best he surrendered to God, the only one he could ask for please. Al-Ghazali's Zarakkal which was done by Al-Ghazali was considered a high level of resignation, that is, like the condition of a person who is jaundiced, sometimes he will remain safe, or he will disappear. ${ }^{66}$ Zaritsa is like in this condition, where there is nothing more she can do to the evil of the Egyptians in front of her. Only God's help is expected.

\footnotetext{
${ }^{63}$ Abû Hâmid al-Ghazali, Ibya 'Ulum Ad-Din, Vol. 4, 97.

${ }^{64}$ Abû Hâmid al-Ghazali, Ibya 'Ulum Ad-Din, Vol. 4, 301.

${ }^{65}$ Abû Hâmid al-Ghazali, Ibya 'Ulum Ad-Din, Vol. 4, 289-290.

${ }^{66}$ Abû Hâmid al-Ghazali, Ibya 'Ulum Ad-Din, Vol. 4, 349.
} 
5. Mahabbah (Love)

Muhammad Kamal Ihsan in his novel says that mahabbah or love has a power that is not possessed by any point in life. Love exists as a bodyguard for all elements of attitude and character. In addition, love is also a driver of enthusiasm and evocative of good desires. Its strength is needed in every struggle to foster awareness of gratitude, patience, confidence, sincerity, and honesty. ${ }^{67}$

There is only one love whose glory is incomparable, that is love to Allah Almighty. The Mighty One and the Owner of all love. As mentioned by Al-Ghazali that love for God is the main goal and is the highest degree. ${ }^{68}$ There is love that without without all love there will be no meaning, namely love to the Prophet. Besides that, other love is allowed as long as it does not exceed the two love. ${ }^{69}$

Whereas Al-Ghazali said that only Allah has the right to be loved. only. People who love besides Allah in terms of their relationship to God are actually caused by ignorance and lack of ma'rifah to Allah. But love for the Prophet is a commendable love because love for the Prophet means love for Allah. So is the case with love for scholars and pious people, because those who are loved are people who are also loved by Allah. All returned to loving the origin, Allah Almighty. So the essence is that there are no people who are loved by people who have a heart vision except Allah swt. ${ }^{70}$

In the story, Zaritsa realizes Raka through her writing that God has given His love to Raka through the beauty of His creation, so that it was knocked on his heart and regretted his mistakes. This is what is called by Al-Ghazali if Allah likes someone, so he makes him repent before his death, so that his past sin does not endanger him even though there are many. ${ }^{71}$

Love is 'one comma' which is discussed quite long as patience and gratitude in this novel, both in the story, and in the reviews. As mentioned by Al-Ghazali before that only Allah has the right to be loved. This necessity is caused by five things: first, the love of man to himself who must have a deficiency as a living being. Second, namely someone's love for someone who does good to him. Third, love for people who do good on themselves, even if they don't feel their good deeds. Fourth, is the love of every beautiful thing because of the beauty itself, not because of the other benefits obtained from the beauty. Fifth, namely conformity and equality, because the similarity of something can attract him. ${ }^{72}$

\section{Sincerely}

In this novel, sincerity becomes the fifth 'point' that must be possessed and passed to feel a happiness. Muhammad Kamal Ihsan said that sincerity is often faced with a test that requires patience to be the support. As Zaritsa's heart condition was required to be able to be sincere for the provisions outlined for her, when she got the news that her father - a figure that meant a lot to her - had to leave her forever.

The sincere state mentioned by Muhammad Kamal Ihsan in this section is called by Al-Ghazali as a blessing, not sincere. This is because sincere according to

\footnotetext{
${ }^{67}$ Muhammad Kamal Ihsan, 5 Titik 1 Koma, 251.

${ }^{68}$ Abû Hâmid al-Ghazali, Ibya 'Ulum Ad-Din, Vol. 4, 392.

${ }^{69}$ Muhammad Kamal Ihsan, 5 Titik 1 Koma, 200-201.

${ }^{70}$ Abû Hâmid al-Ghazali, Ibya 'Ulum Ad-Din, Vol. 4, 401.

${ }^{71}$ Abû Hâmid al-Ghazali, Ibya 'Ulum Ad-Din, Vol. 4, 435-436.

${ }^{72}$ Abû Hâmid al-Ghazali, Ibya 'Ulum Ad-Din, Vol. 4, 401-408.
} 
Al-Ghazali is purifying charity from all mixes and doing it solely in order to get closer to Allah ${ }^{73}$. Whereas the blessing according to Al-Ghazali is the fruit of love, if it has remained a picture of his love for Allah and lost his sorrow because of that love ${ }^{74}$, then that love that causes pleasure with all the actions of a loved one. Accepting the provisions outlined by God is a form of human pleasure for His destiny.

Then what about worship and remembrance just because of expecting heaven and fearing hell? Muhammad Kamal Ihsan wrote this in a poem about sincerity.

God, if you are tired of my forehead kissing the ground just out of fear of Your hell. Then burn me!

God, If I waste my time by dhikr and hope Your heaven. Then expel me! $!^{75}$

Regarding this, Al-Ghazali quoted Ruwaim as saying, "Sincerity in charity is that the culprit does not want the reward for the act in two countries (the world and the hereafter)". Al-Ghazali mentions that this gives a signal that self-profit is a danger in the present (world) and will come (hereafter). So people who worship to get pleasure with lust in heaven are people who are sick. Even the nature of the deeds should not be desired except because Allah Almighty. This is a signal to the sincerity of shiddîqîn namely absolute sincerity. ${ }^{76}$

Al-Ghazali called those who do charity because they expect heaven and fear hell, then he can be called a sincere person compared to the immediate benefits or benefits that exist in the world. Because if not, he will always look for the benefits of stomach and pubic. Indeed, what is truly sought by people who are merely purely the face of Allah. ${ }^{7}$

Muhammad Kamal Ihsan said sincerity is a secret between Allah. with His servant. No one knows even though the recording angels of good deeds. Even Satan will never know, so he will not be able to destroy it. Likewise the passions that will not be able to realize it so that it will not be able to disturb him. So that a sincere affair will immediately be confronted with God without any matter. ${ }^{78}$

Related to this, Al-Ghazali mentions that there are dangers that can interfere with sincerity, some of which are clear, some are hidden, some are clear and weak, then some others are strong and hidden. The sincerity mentioned by Muhammad Kamal Ihsan which can no longer be damaged by the devil and lust is truly true sincerity. It is not sincere as if it is clearly seen but in it is hidden a subtle danger that undermines the sincerity of his heart, especially in matters of worship.

The author mentions that sincerity has a strong relationship with pleasure. Ikhlas is desiring the pleasure of Allah without any influence of worldly elements. Because in truth there is not one true foundation in deeds and good except Allah. If it is still lust, position, property, and fame that is still in the heart, then it means that in his heart is still full of despicable taints. ${ }^{79}$

Al-Ghazali mentions by knowing the level of sincerity in him, he will be careful in his actions and guard the heart from subtle dangers that can damage sincerity,

\footnotetext{
${ }^{73}$ Abû Hâmid al-Ghazali, Ibya 'Ulum Ad-Din, Vol. 4, 505.

${ }^{74}$ Abû Hâmid al-Ghazali, Ihya 'Ulum Ad-Din, Vol. 4, 462.

${ }^{75}$ Muhammad Kamal Ihsan, 5 Titik 1 Koma, 236.

${ }^{76}$ Abû Hâmid al-Ghazali, Ibya Ulum Ad-Din, Vol. 4, 507.

${ }^{77}$ Abû Hâmid al-Ghazali, Ibya 'Ulum Ad-Din, Vol. 4, 507.

${ }^{78}$ Muhammad Kamal Ihsan, 5 Titik 1 Koma, 186.

${ }^{79}$ Muhammad Kamal Ihsan, 5 Titik. 1 Koma, 189.
} 
because it is said that two raka'at from people who have knowledge are more important than a year of worship from fools . Stupid people just look at worship zahir and be fooled by it. ${ }^{80}$

7. Honest

In this novel, honest is the third point that must be passed. The author mentions that honest is something that is very expensive when juxtaposed with anything in this world. Because in heaven someday, honestly becomes the belle of the nature of the inhabitants of heaven. However, the biggest challenge to being able to stand firm in honesty is the emergence of worry, such as worrying about losing office, popularity, and happiness. ${ }^{81}$

In the story, Zaritsa gives a lesson about honesty to Hisyam through the letter he left behind. At that time Hisyam had the habit of picking up the wallets of people in the old market. Although his intention was to pick it up so he could save his father from people who wanted to do evil to him, by giving the money stolen.

The author mentions that the first step in honesty is to avoid lying in every word, because honesty is the beginning of the entry of intention, attitude, character, and every line of life. Therefore honesty is so valuable. Honest is the right action of intention and mind, then speech and words, up to attitudes and actions. Honest is one of the noble qualities of man who can illuminate the path of human life in the world. Honestly like a lamp that if the light goes out, it will lead to darkness and error. $^{82}$

Al-Ghazali mentions that the first level of honesty is honest in words. This includes being honest in conveying information or news and keeping promises. This is the most famous and clear meaning of honesty, whoever manages to keep his oral from lying in his words can be said to be an honest person. However, there are two honest or true perfection in these words, namely: first, guarding from innuendos and second, keeping the honesty of his words in favor of Allah. Like the words "Only to us we worship", if he has a worship other than Allah, he has lied. For example when he says "I am a servant of God" then on the Day of Judgment he will be prosecuted for his words. If it turns out that he is only a servant of himself, a servant of the world, or a servant of his lust, then he is not honest in his words. ${ }^{83}$

Without honesty, the world will collapse and collapse. This is because honesty is the main pillar of life for the earth which fights for rights and truth. The author quotes al-Ghazali's words which divide honesty with five. Namely, honest in every word, intention, willingness, promise, and all deeds. ${ }^{84}$ Besides the five things cited by the author regarding various types of honesty, there is one more kind of honesty that is called by Al-Ghazali that is honest in realizing positions in religion. ${ }^{85}$

d. The Happiness ofNovel 5 Titik 1 Koma by Muhammad Kamal Ihsan

Through five 'titik' and one a koma' which are the main themes depicted by the character Zaritsa in this novel, Muhammad Kamal Ihsan formulates that there are six

\footnotetext{
${ }^{80}$ Abû Hâmid al-Ghazali, Ibya 'Ulum Ad-Din, Vol. 4, 510.

${ }^{81}$ Muhammad Kamal Ihsan, 5 Titik 1 Koma, 115-116.

${ }^{82}$ Muhammad Kamal Ihsan, 5 Titik 1 Koma, 149-150.

${ }^{83}$ Abû Hâmid al-Ghazali, Ibya 'Ulum Ad-Din, Vol. 4, 515-516.

${ }^{84}$ Muhammad Kamal Ihsan, 5 Titik 1 Koma, 151.

${ }^{85}$ Abû Hâmid al-Ghazali, Ihya 'Ulum Ad-Din, Vol. 4, 515.
} 
aspects that must be possessed to achieve true happiness. These five points are gratitude, patience, confidence, honesty, sincerity, and love.

As many similarities in the meaning of the six elements of happiness by Muhammad Kamal Ihsan with Al-Ghazali's thinking, the formulation of happiness is also in harmony with the formulation of Al-Ghazali's happiness. Al-Ghazali mentions in Kimyâ As-Sa'âdah (Chemistry of Happiness) four elements that must exist to obtain spiritual happiness namely knowledge of self, knowledge of God, knowledge of the world, and knowledge of the hereafter. ${ }^{86}$

If someone has known these four things, then surely he will carry out the six elements mentioned by Muhammad Kamal Ihsan in his novel. So that true happiness that is eternal is achieved. Not just the happiness of the world, but also the happiness of the hereafter that is eternal forever.

\section{Conclusions and Suggestions}

Based on the results of the study, it can be concluded that the novel 5 Titik 1 Koma by Muhammad Kamal Ihsan contains aspects of akhlaki and amali sufism that are in line with Sufism Al-Ghazali's thinking, especially in the stages (maqâmat) and conditions (ahwâl) by which a person sâlik. However, there are differences in the formulation of elements of happiness that must be possessed, even though basically they are interconnected in their implementation.

This novel tells the story of the struggle of a mute woman who is studying in Egypt named Zaritsa through the main character named Ihsan. Zaritsa's determination has provided extraordinary experiences for other characters in this novel, so that they become better people and are more grateful to God for all the pleasures they feel. In addition to containing stories, this novel also contains an explanation of five points and one comma itself, namely gratitude, patience, confidence, sincerity, honesty, and love.

The Sufism aspect contained in this novel which is also explained by AlGhazali in the form of maqamat is a spiritual level that must be attained by a sâlik and ahwal, namely the mental condition of a salik. Maqâmât and abwâl contained include: Repentance, patience and gratitude, zuhud, tawakkal, mahabbah (love), sincerity, and honesty. Everything is in accordance with what was mentioned by $\mathrm{Al}$ Ghazali, but there are differences in the use of terms such as the use of sincerity in the face of all the tests that Al-Ghazali called ridha.

In addition to Maqamat and Ahwal, this novel also contains the formulation of happiness that will be achieved by Jiaka humans to have gratitude, patience, confidence, sincerity, honesty, and love. The formulation of happiness is in line with Al-Ghazali's view, but Al-Ghazali uses a different language, namely knowing oneself, knowing God, knowing the world, and knowing the hereafter. By recognizing these four things, then someone will surely be grateful, patient, confident, sincere, honest, and love as mentioned by the novelist.

The suggestions conveyed based on this research are novel writers, especially Islamic novels to better popularize Sufism values, given the large number of people interested in reading novels compared to reading religious books directly. Researchers are expected to enrich their studies with other methods of literary

${ }^{86} \mathrm{Al}-\mathrm{Ghazali}$, Kimiya Al-Sa'adah: Kimia Rubani untuk Kebahagiaan Abadi, trans. Dedi Slamet Riyadi dan Fauzi Bahreisy (Jakarta: Zaman, t. th), 5-6. 
research, so as to add to the treasures for research in literature, in the form of novels, films, poems, short videos, poems, songs and so on.

\section{BIBLIOGRAPHY}

Al-Ghazali, Abû Hamîd, (2015). Ibyâ 'Ulum Al-Din.Vol. 1. Beirut: Dâr al-Kutûb al'Ilmiyah. , (2015).Ibya Ulum Al-Din.Vol. 2. Beirut: Dar al-Kutub al-Ilmiyah. , (2015). Ibya 'Ulum Al-Din.Vol. 3. Beirut: Dar al-Kutub al-Ilmiyah. , (2015). Ibya 'Ulum Al-Din.Vol. 4. Beirut: Dar al-Kutub al-Ilmiyah. , (1993). Ibya Ulum-id-din. Vol. IV. terj. Fazl al-Karim. Pakistan: Darul Ishaat. , (2009).Terjemah Ibya Ulumiddin. Jil. VII. terj. Moh Zufri, dkk. Semarang: Asy-Syifa' Press. , (2009). Terjemah Ihya Ulumiddin. Jil. VIII. terj. Moh Zufri, dkk. Semarang: Asy-Syifa' Press. , (2009). Terjemah Ibya 'Ulumiddin. Jil. IX. terj. Moh Zufri, dkk. Semarang: Asy-Syifa' Press. , (2003). Arbain Al Ghazali, terj. M. Said Su'di. Yogyakarta: Pustaka Sufi. , Kimiya Al-Sa'adab: Kimia Ruhani untuk Kebahagiaan Abadi, terj. Dedi Slamet Riyadi dan Fauzi Bahreisy. Jakarta: Zaman, t. th.

Asmaran, (1996). Pengantar Studi Tasawuf. Jakarta: PT Raja Grafindo Persada. , (2013) Teori Makrifah al-Ghazali: Sebuah Karakteristik Epistemologi Islam. Banjarmasin: IAIN Antasari Press.

Dewan Redaksi Ensiklopedi Islam, (2001). Ensiklopedi Islam. Jil. 2. Jakarta: PT Ikhtiar Baru van Hoeve. , (2001).Ensiklopedi Islam. Jil. 5. Jakarta: PT Ikhtiar Baru van Hoeve.

Eriyanto, (2011). Analisis Isi: Pengantar Metodologi untuk Penelitian Ilmu Komunikasi dan Ilmu-Imu Sosial Lainnya. Jakarta: Prenadamedia Group.

Faridy, Heri MS dkk, ed (2008). Ensiklopedi Tasawuf. Bandung: Angkasa.

Haeri,Fadhlalla.The Element of Sufism, terj. Ibnu Burdah dan Shohifullah. Yogyakarya: PustakaPelajar, 2000.

HAMKA, (2015). Tasawuf Modern. Jakarta: Republika.

Ihsan, Muhammad Kamal, (2018). 5 Titik 1 Koma. Bandung: CV. Rasi Terbit.

Isa, Abdul Qadir, (2007).Haqa'iq 'an at-Tashawnuf. Aleppo: Dar al-'Arifin.

JA, Denny(2017). Bahagia itu Mudah dan Ilmiah. Depok: Kata Depan.

Mahayana,Maman S, (2015). Kitab Kritik Sastra. Jakarta: Yayasan Pustaka Obor Indonesia.

Mahmud, Abdul Halim, (2002). Tasawuf di Dunia Islam. Bandung: Pustaka Setia.

Nasution, Muhammad Yasir, (1996). Manusia Menurut Al-Ghazali. Jakarta: Srigunting.

Nursisto, (2000). Ikbtisar Kesusastraan Indonesia. Yogyakarta: Adicita Karya Nusa.

Redaksi PM, (2012). Sastra Indonesia. Depok: Pustaka Makmur.

as-Sarraj, Abu Nashr, (2002). Al-Luma'.terj. Wasmukan dan Samson Rahman. Surabaya: Risalah Gusti.

Senali, Moh. Saifullah Al Aziz, (1998).Risalab Memahami Ilmu Tasawuf. Surabaya: Terbit Terang.

Shihab, M. Quraish, (2016). Yang Hilang dari Kita: Akblak. Tangerang: PT. Lentera Hati. 
Solikhin, Muhammad, (2013). Sufi Modern: Mewujudkan Kebahagiaan, Menghilangkan Keterasingan. Jakarta: PT Gramedia.

Sudardi, Bani, (2003). Sastra Sufistik: Internalisasi Ajaran-ajaran Sufi dalam Sastra Indonesia. Surakarta: Tiga Serangkai Pusataka Mandiri.

Sugiarto, Eko, (2013). Menyusun Proposal Penelitian Kualitatif Skripsi dan Tesis. Yogyakarta: Suaka Media.

Sukardi, Imam, (2005). Puncak Kebahagiaan Al-Farabi: Etape-etape Sufistik-Filosofis Meniti Revolusi Hidup. Yogyakarta: Pustaka Pelajar.

Zaini, Ahmad, (2016). "Pemikiran'Tasawuf Imam Al-Ghazali", Esoterik: Jurnal Akblak dan Tasawuf.Vol. 2 No. 1.

Zaprulkhan, (2016). Ilmu Tasawuf: Sebuah Kajian Tematik. Jakarta: Rajawali Pers. 